\title{
Chromo therapy- An Effective Treatment Option or Just a Myth?? Critical Analysis on the Effectiveness of Chromo therapy
}

\author{
Somia Gul ${ }^{1}$, Rabia Khalid Nadeem and Anum Aslam \\ Faculty of Pharmacy, Jinnah University for Women.
}

\begin{abstract}
:
Background: Chromo therapy or commonly color therapy falls under the category of Complementary and Alternative Medicine System (CAMS) of treatment by utilizing electromagnetic radiations with different frequencies which effects human nuerohormonal pathways and can be helpful to cure diseases. It is one of the most successful ancient practices which are now gaining interest as a valid and effective science. It is a well established fact that chromo therapy triggers the specific points in our body and relieves various ailments.

Objective: Prevalence of chromo therapy as an alternative and complementary treatment option and to raise awareness of its magnificent effects.

Methodology: People are using chromo therapy as a complementary as well as an alternative treatment option worldwide. In current studies, survey has been conducted in different educational institutions, hospitals, locality and online data. Close ended questionnaire has been distributed to a sample size of 200 individuals $(n=200)$.

Results: The studies have proved that chromo therapy has tremendous effects on diseases like cancer specially breast cancer, hematoma (red), hepatitis B (combination of various lights), hypertension, neonatal jaundice (blue light), spondylosis, peptic ulcer disease (yellow light), depression and stress, migraine (green light), hyperthyroidism (violet/blue light), alopecia (violet), color blindness (blue/ green) and various skin infections specially cutaneous leishmaniasis (blue and red). Studies have shown that 56.5\% individuals of the targeted population, are aware of chromo therapy and 33\% of them are in favor that this should prevail as an alternative as well complementary treatment option, due to its minimal or no side effects and its effectiveness.
\end{abstract}

Conclusion: Current studies concluded that chromo therapy is a natural way to cure various ailments, utilizes worldwide. Further it illustrates that chromo therapy is an effective evolution of science in the field of electromagnetic radiation/energy and it can be very helpful in discovering new dimensions of treatment.

Keywords: chromo therapy, electromagnetic radiations, leishmaniasis, breast cancer, hepatitis B

\section{INTRODUCTION}

Nature has undisputable effect on body physiology. Colors have potential to cause a dominant effect on our sensations and senses. Man still relies on light and appealed by colors. Dynamic influences of colors on human body are undeniable. It has been healing mankind in the form of chromo therapy from centuries, [1] Chromo therapy/color therapy is a method of treatment that uses the visible spectrum (colors) of electromagnetic radiations (wavelength 7700-3900 AU) and invisible spectrum (infrared and UV), to cure diseases [2]. There are specific sites (centers) in body which absorbs color of varying wavelength and produce effect $[3,4]$. When the ratios of the required colors in one or more centers of the body imbalances, it gives rise to the various ailments and when the colors are balanced, diseases are easily cured. In order to overcome the deficiency or to normalize excess of a color, sunlight or artificial lights are used [5,6]. Each color generates electrical impulses and field of energy that serves as activators of biochemical and hormonal processes. So, the dysfunction of body organs can be treated by chromo therapy [7, 8].

Previous studies has been conducted in this regard has proven the fact that there is a specific color for each organ that affects the human body by producing physiological and/ or psychological effects $[9,10]$ if specific organ is concerned, low energy level (infrared) light i.e. blue and violet, can be employed in the clinical management of migraine which arise due to stress, lack of blood volume (following from pregnancy or at the end of menstruation)

\footnotetext{
${ }^{1}$ Corresponding Author: drsomi1983@yahoo.com
} 
or low blood pressure.[8,11,12] Also, it attenuates hyperglycemia-induced oxidative stress and enhances the antioxidant protection system $[13,14]$ also, chromo therapy is found to be beneficial in long term management of stress in patients with stroke by using vibrant colors in their surroundings [11]. Previous analysis has demonstrated the effects of visible range irradiation (in vitro) on the enzyme solutions (glucose oxidase, cholesterol oxidase + cholesterol esterase and lipase) and Superoxide Dismutase (SOD) in order to infer the changes produced in the human body after chromo therapy were studied, and researchers found tremendous elevations in theses enzymatic activity $[9,15]$ also, the stimulatory and calming effects of red and blue lights, respectively, cannot be denied specially, in the cases of muscular spasm in calf muscles [16, 17]

As far as psychological effects of colors are concerned, we have come to know that colors are really beneficial for man in every respect. [13] For instance, Post Traumatic Stress Disorder [PTSD] is a severe psychological traumatic condition in which a patient may develop a series of uncontrolled flashbacks. It is believed that this abnormal psychological and abnormal behavior is due to hyperactivity of amygdalus and hippocampus or low responsivity of hippocampus, rostral anterior cingulated cortex. Researchers used a new technique, in order to vanish the painful disturbing memories "Eye Movement \& Desentization Reprocessing (EMDR)" accompanied by "Auriculochromotherapy", which served as a path between external ear and affected brain parts.

This was done by applying yellow laser light at sensitive parts of ear which were identified primarily by palpitating the ear lobe. The response was that painful memories disappeared completely after one minute of exposure and at the same time emotions connecting to painful images were also decreased.[23,24] A series of investigations have demonstrated chromo therapy clinically effective and safe in patients with acute respiratory disease, acute tonsillitis, cervical dorsipathies, vegetative dysfunction and in stroke and hypertensive out-patients. It serves as bacteriocidal, anti inflammatory and vegeto-corrective therapy [12, 1, and 16]

Table1. Forms of Colors That Can Be Used Therapeutically

\begin{tabular}{|c|c|c|c|c|}
\hline Colors & $\begin{array}{c}\text { Wavelengt } \\
\mathrm{h}(\mathrm{nm})\end{array}$ & $\begin{array}{l}\text { Specific } \\
\text { color }\end{array}$ & $\begin{array}{c}\text { Psychological } \\
\text { implementation }\end{array}$ & Physiological implementation \\
\hline Red & 644 & $\begin{array}{l}\text { Sacral } \\
\text { region }\end{array}$ & $\begin{array}{l}\text { Vitality, strength, sexuality, } \\
\text { will power \& alertness[18] }\end{array}$ & $\begin{array}{l}\text { Increases glucose } 9 \text { xidase activity, lea ding } \\
\text { to glucose oxidation, used for diabetes \& } \\
\text { increases superoxide dismutase, removal } \\
\text { of toxins, muscular spasm [15] Anemia, } \\
\text { fatigue, impotency, hypotension [18] } \\
\text { increased metabolism and appetite[19] } \\
\text { increases blood pressure[20] }\end{array}$ \\
\hline Orange & 610 & $\begin{array}{l}\text { Sacral } \\
\text { region }\end{array}$ & Happiness, joyousness[21] & $\begin{array}{l}\text { Circulation and metabolism, depression, } \\
\text { mood swings [20], renal and pulmonary } \\
\text { disorders [18] Thyroid, pimples, fistulas, } \\
\text { diabetes [20] }\end{array}$ \\
\hline Yellow & 590 & Diaphragm & $\begin{array}{l}\text { Intellect and judgment, } \\
\text { mental stability and } \\
\text { concentration [22] }\end{array}$ & $\begin{array}{l}\text { Used in auriculochromotherapx with Eye } \\
\text { Movement Desensitization Reprocessing- } \\
\text { technique[23,24] Rheumatism and } \\
\text { arthritis, stress induced disorders, weight } \\
\text { loss [19], skin problems and stomach } \\
\text { ailments }[25,20,26]\end{array}$ \\
\hline Green & 538 & Heart & Purity and hamony [21] & Rejuvenation \& metabolism [20] \\
\hline Blue & 453.5 & Throat & $\begin{array}{l}\text { Will power and } \\
\text { communication, } \\
\text { management of migraine } \\
\text { due to psychological } \\
\text { factors[20] }\end{array}$ & $\begin{array}{l}\text { Asthma, migraine[12], stress induced- } \\
\text { disorders, poisoning treatment, ENT } \\
\text { issues }[20] \text { appetite suppression }[23,26] \\
\text { fatigue }[20,27]\end{array}$ \\
\hline Indigo & & $\begin{array}{l}\text { Brow/ } \\
\text { forehead }\end{array}$ & $\begin{array}{l}\text { Dignity, honour, self } \\
\text { respect and hope [19] }\end{array}$ & Mental and nervous disorders [28] \\
\hline violet & 400 & & $\begin{array}{l}\text { Spirituality, letting-go and } \\
\text { meditation }\end{array}$ & $\begin{array}{l}\text { Increases cholesterol esterase, used for } \\
\text { diabetes [18.29]regulates endocrine } \\
\text { system [20] migraine[12, 26] }\end{array}$ \\
\hline
\end{tabular}

\section{DEVELOPMENT OF COLOR INTO COLOR THERAPY}


Chromo therapy is a centuries which was started from the Egyptian era [3, 24]. In A.D 980, Ibn Sina (Avicenna) formulated a chart of various colors and brought up the concept of warming and cooling colors [29]. In 6th century BC Orpheus, used vibrational medicine of color and light as a mode of healing [30]. Apuleius revealed the diagnosis of epilepsy with a flickering light. Ptolemy, proposed the concept, that when light entered into eyes, stimulated the specific brain centers and produced a feeling of euphoria (due to the release of 'feel-good' hormone-serotonin) in a person[31]. Middle Ages in 1493, Paracelsus reintroduced the color philosophy and used color with music and herbs as a complementary medicine. [25] In 1666 Sir Isaac Newton formed a wheel which of colors that is harmonious together, and other colors that might clash. [32] Johann Wolfgang Goethe observed the principle, called "polarity and elevation. "It says that only those colors can be combined together which have no or little difference of polarity. [13] Edwin Burr Babbitt (1803-1881) revealed stimulatory effect of red color on blood, soothing effect of violet/blue to be used as anti inflammatory and yellow/ orange as laxative. [28, 33] Ewald Hering gave opponent colour processes theory, based on two opponent systems which posses' inhibitory and excitatory responses, controlled by opponent neurons, (neurons which respond to specific wavelength). [34] Dr. Ott (1997) was the first person to evaluate the effect of chromo therapy at the DNA level [14] Dr. Harrah Conforth (1991) applied colour and light to facilitate whole Brain synchronization [35]

Table 2: Physiological and Psychological Influence of Colors Due To Their Specific Wavelength Targeting Specific Organ

\begin{tabular}{|l|l|}
\hline $\begin{array}{l}\text { Therapeutic forms of } \\
\text { color }\end{array}$ & Effects \\
\hline $\begin{array}{l}\text { Exposure to colored } \\
\text { lights }\end{array}$ & Coloured light is concentrated over the affected part of the body[34] \\
\hline Solarized water and oil & $\begin{array}{l}\text { Water oil filled colored bottles glass bottles are exploit colored, and allowed to } \\
\text { solarized for } 4 \text { hours (water) and a week for (oil), to get charged and absorb the } \\
\text { vibrational energy of that particular color. } \\
\text { This solarized water can be taken orally, and oil can be used as topical } \\
\text { preparation.[13,10] }\end{array}$ \\
\hline Color tratak & $\begin{array}{l}\text { Colored cloth paper is placed three feet away from eye level, and the person is } \\
\text { adviced to focus on the colored material and feel the intensity of color is } \\
\text { penetrating inside.[29,36] }\end{array}$ \\
\hline Color breathing & $\begin{array}{l}\text { It is a virtual breathing system, You have to think that you are inhaling a } \\
\text { particular colour and exhaling another colour which is complement to it[13,37] }\end{array}$ \\
\hline
\end{tabular}

Prevalence of chromo therapy as an effective adjunct with conventional medicine and to create awareness regarding its miraculous influences on our body and soul

\subsection{Methodology}

In order to gain knowledge about the awareness and use of chromo therapy, a generalized closed-ended survey was conducted in various localities and educational institutions of Karachi. In this survey sample size of $200(\mathrm{n}=200)$ individuals has been selected comprised of three different age groups, 15-25 yr, 26-36 yr and $36 \mathrm{yr}$ onwards were cross-examined. Data was collected within a month of Aug'2014. A specialized questionnaire was designed which includes16 questions in all focusing on the general perception and believe of people regarding chromo therapy, techniques and medication used, its effectiveness and prevalence. Also, we evaluated the side effects and inconvenience experienced by participants which undergone through chromo therapy.

\subsection{Data Analysis}

The current research results are formulated and expressed graphically. Parameters like general awareness about the chromo therapy, treated population, effectiveness, side effect profile and its prevalence ratio is expressed by using bar charts (fig.1, 2, 3, 5,7). Also, pie charts (fig. 4, 6, 8) are used to express the evaluation of the targeted population regarding the diseases which have been treated by chromo therapy and factor involved in its prevalence. 


\section{RESULTS AND DISCUSSION}

Chromo therapy is the method of treatment that uses the visible spectrum (colors) of electromagnetic radiations (wavelength 7700-3900 AU) and invisible spectrum (infrared and UV), to cure diseases. There are specific sites (centers) in body which absorbs color of varying wavelength and produce effect. In current analysis, out of 200 individuals 56.5\% (113/200) people have knowledge about chromo therapy, and 38\% individuals have treated by it (fig. 1, fig. 2) and $90 \%$ found it very effective while $86 \%$ says to some extent it is an effective treatment (fig 3). $11 \%$ of the people believed that it is effective against hepatitis, hematoma, hypothyroidism, Alopecia, spondylosis, skin diseases, (14\%) various types of cancer, breast cancer, (13\%) hypertension. (20\%) and (17\%) cases were of peptic ulcer disease and neonatal jaundice, respectively (fig 4).

While cross-examination of the collected data, it was observed that chromo therapy has very low side effect profile, only $5 \%$ says they experienced side effects (fig 7 ). Out of treated population, only $2 \%$ individuals used medication during chromo therapy (table 3).

People gave quite a positive response regarding the future prevalence. $54 \%$ are in favor of chromo therapy should be used as basic treatment option (fig 6), 31\% believes that it should be prevalent (fig 7).

Chromo therapy is believed to be a myth but there is complete science behind its tremendous functionality. The current analysis has highlighted its usefulness in various ailments. This therapy is not new it has been going on from many centuries. This was initiated by Egyptians, Native Americans, Greeks, and Indians, and still it is practiced worldwide. A number of researches have been conducted in this regard that brought up new advancement in this field. It has gone through multiple developmental stages.

Doctrine of chromo therapy says it is significantly known fact that there is an electromagnetic field around every object in this world. This electromagnetic field refers to an "Aura" composed of different layers of colors. Each color is associated with a specific energy center in the body, called as "chakras". Chakra (in Sanskrit) means a spinning-wheel, that creates a vacuum in the centre and draws-in, the energy from its surrounding Aura. All organs and limbs of the body have their respective color that corresponds to the surrounding electromagnetic field. There are seven main Chakras or energy centers in the body at different locations. Some people also believed that there is an extended chakra system based on 12 chakras associated with human body, but these lack the power to influence human health, they are said be connected with a person's spirituality.

Seven main chakras are associated with different organs in our body.

$>$ First or Root Chakra, located at the baseline of spine, its master organ is adrenal gland \& it is associated with color red.

$>$ Second or Spleen Chakra, located at the pelvic area, gonads are mainly affected by it \& it is associated by color orange.

> Third or Solar plexus Chakra, located at abdomen, it affects pancreas \& it is associated with color yellow.

$>$ Fourth or Heart Chakra, located at chest, thymus is its master gland \& it is associated with color green

$>$ Fifth or Throat Chakra, thyroid is the master gland \& it is associated with color blue

$>$ Sixth or Brow Chakra, located at brow, mainly affects pineal gland \& it is associated with indigo

$>$ Seventh or Crown Chakra, located at the crown area, master gland is pituitary \& it is associated with violet

These energy centers or chakras must be balanced. If a person's chakra is thought to be out of balance or weak, the patient is believed to be unhealthy. It is scientifically proven that toxins, negative thoughts, dietary chemicals and environmental factors or any other form of pollutants may aggravate the chakra imbalance. Chromo therapy is a technique that restores the synchronization of theses energy centers by application of healing colors to the body.

Firstly, a chromo therapist needs to rectify the imbalanced chakra and its cause, in order to treat the ailment completely. If the cause persist color therapy can mask the symptoms associated with the ailment. Once the disturbed chakra is identified, its associated color application either directly or indirectly, may provide relief. Now, this color will generate electrical impulses and magnetic field of energy which in turns initiates biochemical and hormonal processes within the body. According to the achieved results of current analysis, it is concluded that chromo therapy is an attractive, non-invasive, cost-effective complementary and alternative treatment option with relatively few negative effects. it is found to be very effective against stress, depression, hypertension, 
hypothyroidism, hepatits B, peptic ulcer disease and conditions associated with it, aloepoecia, spondylosis, hematoma, neonatal jaundice, insomnia, different types of pains even skin infections have also been treated by it, without any noticeable adverse effects!

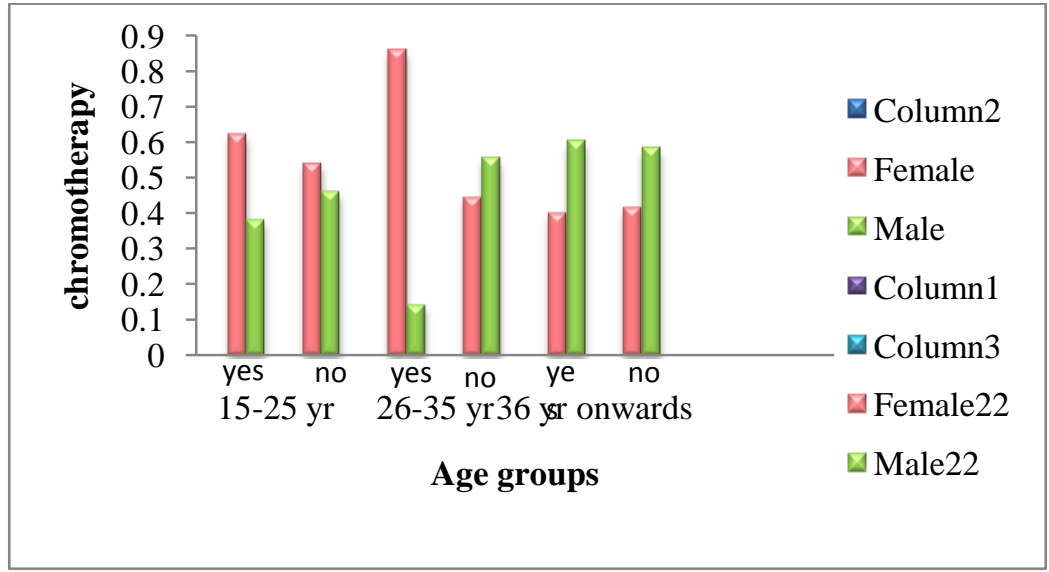

Fig1. General Awareness about Chromo therapy

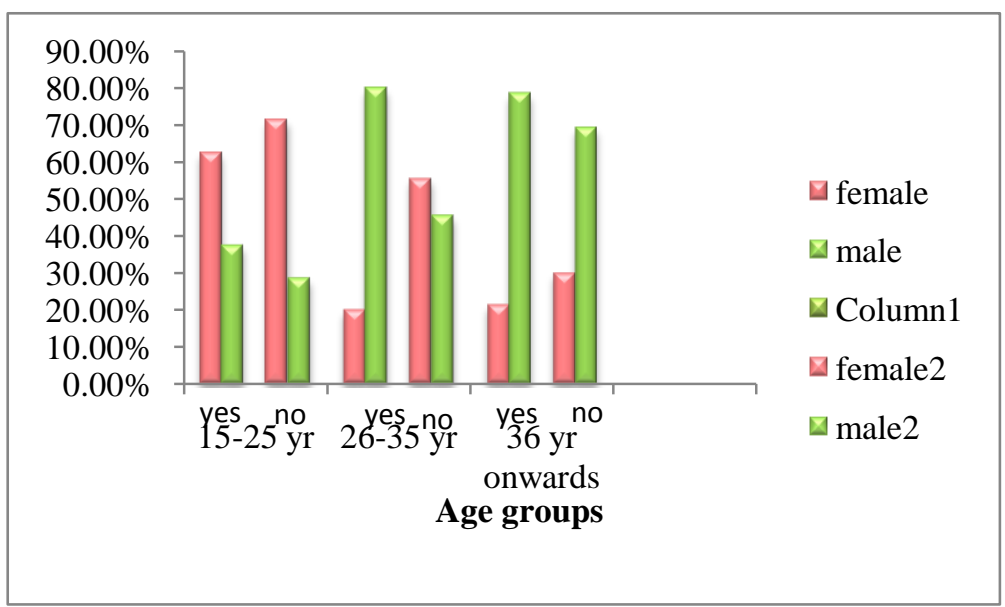

Fig2. Population Treated with Chromo therapy

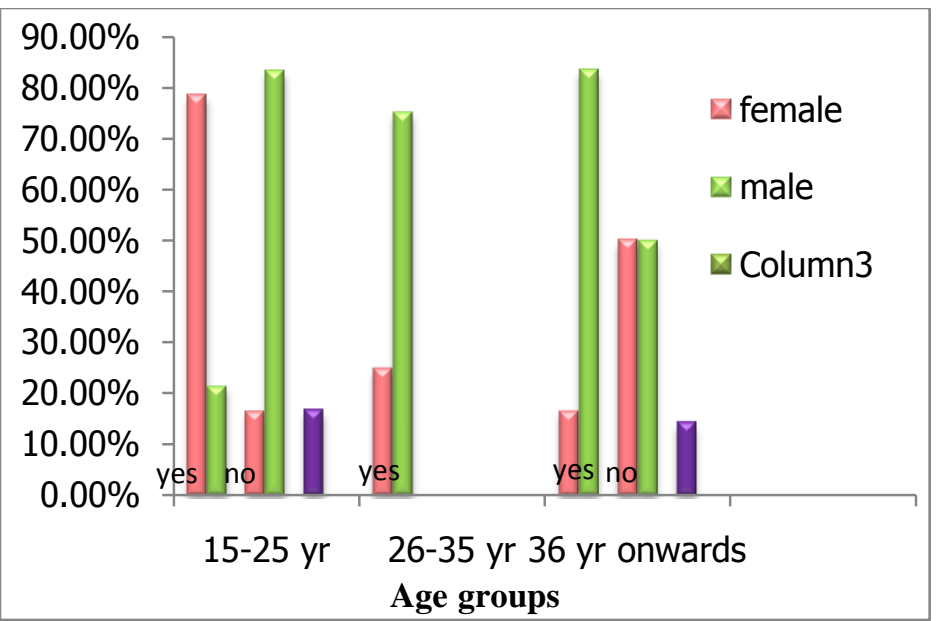

Fig3. Effectiveness of Chromo therapy in Treated population 
American Research Journal of Pharmacy, Volume 1, Issue 2, 2015

ISSN 2380-5706

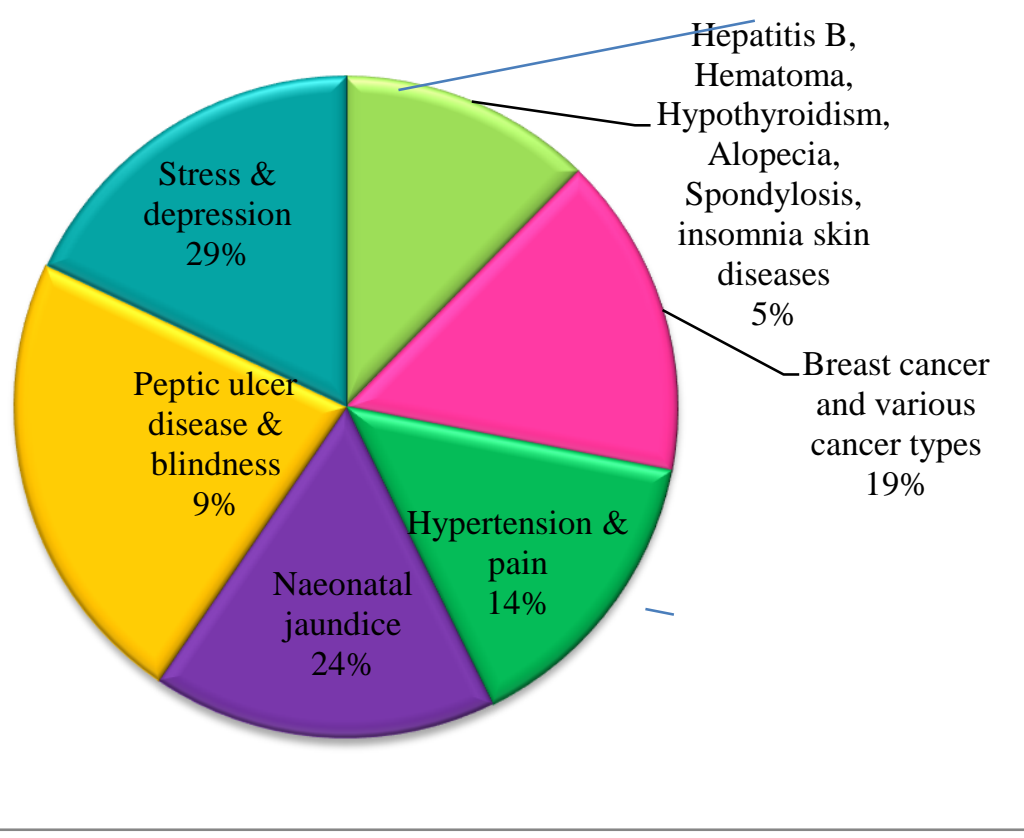

Fig 4. Diseases treated with chromo therapy

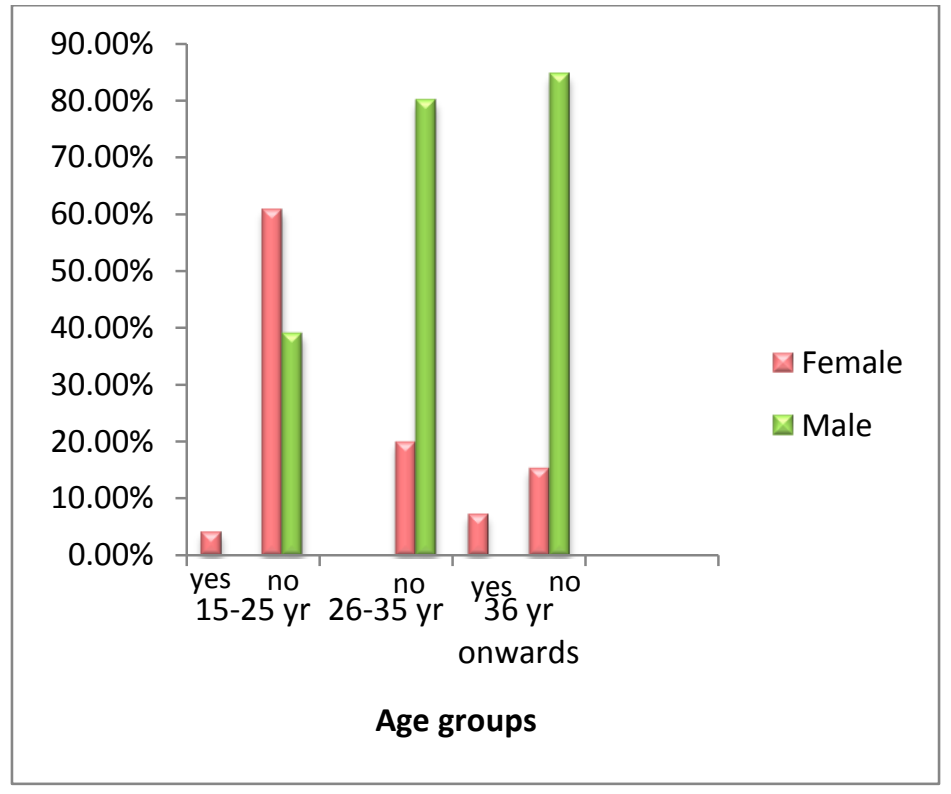

Fig 5. Side Effects

Table 3: Medications used in Chromo therapy

\begin{tabular}{|c|c|c|c|c|}
\hline Age group & \multicolumn{2}{|c|}{ Female } & \multicolumn{2}{c|}{ Male } \\
\hline & Medication & Disease & Medication & Disease \\
\hline $15-25 \mathrm{yr}$ & pentaprazol & Peptic ulcer disease & - & - \\
\hline $26-35 \mathrm{yr}$ & Synthroid & Hypothyroidism & - & Pain \\
\hline $36 \mathrm{yr}$ onwards & Analgesics & Pain & Analgesics & . \\
\hline
\end{tabular}




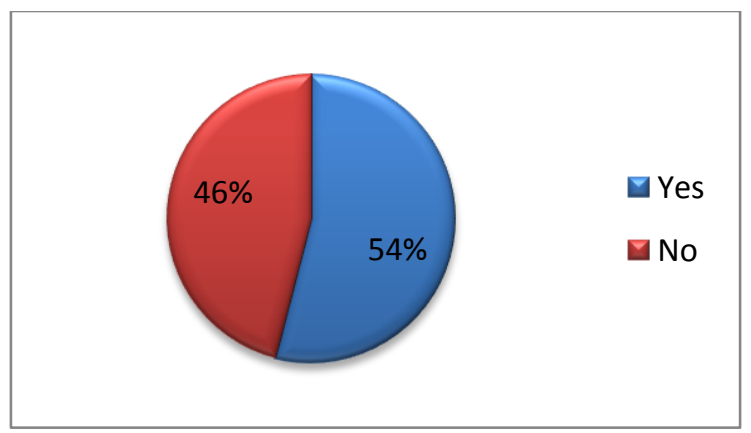

Fig6. Chromo therapy as a basic treatment option

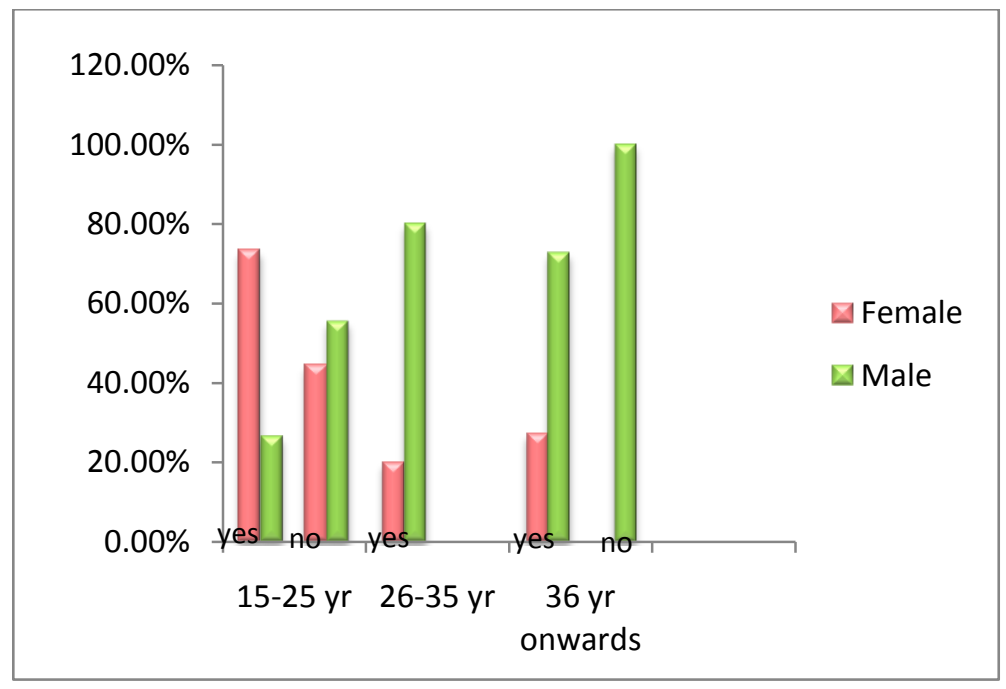

Fig7. prevalence of chromo therapy

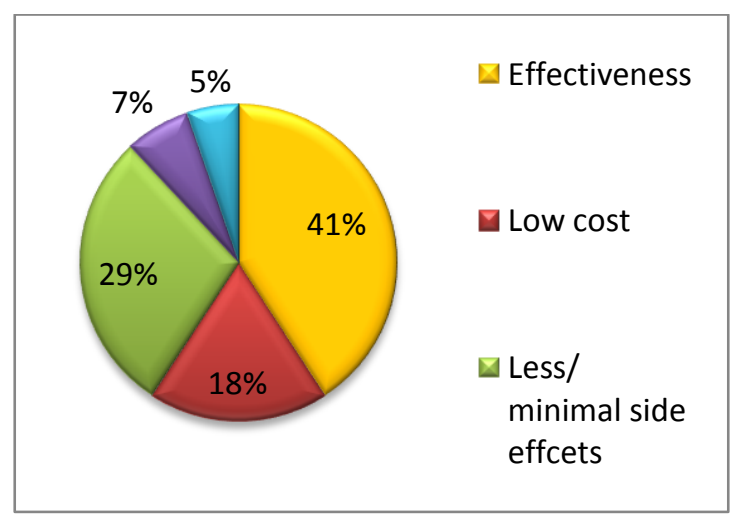

Fig8. Factors Involve In Chromo Therapy Prevalence

\section{CONCLUSION}

These convincing facts regarding chromo therapy have made it one of the most effective and potent complementary and alternative treatment options. But the dilemma is, very few of us are aware of its beneficial aspects. This therapy should be recognized and adopted by physicians to support the conventional therapy. Today, homeopathic, ayurvedic, unani remedies, and Chinese medicinal systems are being incorporated in conventional therapy, then why not colors can be used for the treatment. Chromo therapy works on a principle that optimal distribution and maintenance of various colors (energies) within the body is essential for its normal functioning. It is a complete science which involves biophysics, medicine, psychology. These constituting fields of chromo therapy would widen 
the scope of this important branch of alternate and complementary therapy and can be used as an adjunct to conventional medicine. Surely, chromo therapy has a promising scope in near future as it has a potential to appear as an emerging technology.

\section{References}

[1] Mi Kyoung Kim, Sung Don Kang (2012), Effects of Art Therapy Using Color on Purpose in Life in Patients with Stroke and Their Caregivers, Younsei Medical Journal [online] vol 54 (1).p .15-20 Available from: http://europepmc.org/backend/ptpmcrender.fcgi?accid=PMC3521264\&blobtype=pdf [Accessed: $10^{\text {th }}$ july'2014]

[2] Bo`O Vojnikovi (2010) Chromotherapy Of Macular Degeneration With Transitions Lenses And Green-Yellow Medical Filters And Special Programme For Psycho Organic Disturbances, Collegium Antripologicum [Online] Vol 34(2) P. 89-93 Available From: http://hrcak.srce.hr/index.php?show=clanak\&id_clanak_jezik=79042 [Accessed: $15^{\text {th }}$ July'2014]

[3] Dr. Maqsood Azeemi, (2007) Health And Colors In "Khawaja Shamsuddin Azeemi Color Therapy", Peshawar Cantt.By Burkhiya Education Foundation (Redg.), pg no:26-31 available from: http://www.souldesigns.net/iq_blog/color_therapy.pdf [Accessed: 20 th Jun'2014]

[4] Lexiyoga (2014). Colour Healing Available from: http://www.lexiyoga.com/colour-healing [Accessed: 12th aug'2014]

[5] Color Me Heathy.com (2009), Let color put the life back in your life Available from: http://www.color-mehealthy.com/psychology.html [Accessed on 26th july'2014]

[6] Amara Holistic Well Being (2005), Colour Therapy Available from: http://www.amaraholisticwellbeing/colortherapy.html [Accessed on1st july'2014]

[7] Zena O'connor, (2011), Colour Psychology And Colour Therapy: Caveat Emptor, Color Research \& Application,[online] vol: 36, issue 229-234 Available from: http://onlinelibrary.wiley.com/enhanced/doi/10.1002/col.20597/ [Accessed: $29^{\text {th }}$ Jun'2014]

[8] Eu natural (2003) Color Therapy For Sleep [online] Available from: http://eunatural.com/color-therapy-for-sleep/ [Accessed on:25 ${ }^{\text {th }}$ Aug'2014]

[9] Samina T. Yousuf Azeemi, Syed Mohsin Raza, Masoom Yasinzai, (2008), Colors as Catalysts in Enzymatic Reactions Journal Of Acupuncture And Meridian Studies [online] Vol 1, Issue 2, p 139-142 Available From: http://www.jamskpi.com/article/S2005-2901(09)60034-0/abstract [Accessed on: 12th Jun'2014]

[10] Sarah Dray, (2014) livestrong.com, Colortherapy For Weight Loss [online] Available from: http://www.livestrong.com/article/190776-color-therapy-for-weight-loss/ [Accessed on: 25 ${ }^{\text {th }}$ July'2014]

[11] E. Ewing, G. Ewing1, E.U. Nwose (2009) Migraine Can Be Managed With Virtual Scanning: Case Report, The Open Complementary Medicine Journal,[online] vol 1.p 16-18. Available from: http://benthamopen.com/toaltmedj/articles/V001/16TOALTMEDJ.pdf [Accessed: $20^{\text {th }}$ Aug 2014]

[12] ICBS (2007) Migraine headaches, holisticonline.com [online] Available from: http://holisticonline.com/Remedies/migraine/mig_color.htm [Accessed On 20th Aug'2014]

[13] Dr Linda Mayer and Prof Rashid Bhikha, (2014), The Historical Significance of Colour, Tibb institute - A Science of Medicine The Art Of Care, [onine] part:2 p1-11 Available from:http://www.tibb.co.za/articles/Part-2-Historicalsignificance-of-colour.pdf [Accessed on:25 ${ }^{\text {th }}$ Aug'2014]

[14] Hari Om Gupta,(2007), The Healing Powers Of Chromotherapy Using Colors To Cure Diseases, [online] New Delhi, Sterling Publishers. Available from: http://books.google.com.pk/books?id=HqFgj4KBsDsC\&printsec=frontcover\&source=gbs ge summary $\mathrm{r} \& c a d=0 \# v=0 n e p$ age \&q\&f=false [Accessed on: $14^{\text {th }}$ July'2014]

[15] Samina T. Yousuf Azeemi. S. Mohsin Raza, Masoom Yasinzai, Abdul Samad, (2009), Effect of Different Wavelengths on Superoxide Dismutase, Journal of Acupuncture and Meridian Studies [online] vol: 2(3) p.236-238 Available from: http://www.sciencedirect.com/science/article/pii/S2005290109600601 [Accessed on 15 ${ }^{\text {th }}$ Aug'2014]

[16] Elkina TN, Zakharova (2013),The Experience With The Application Of Selective Polarized Chromotherapy In The Clinical Practice, Medline Journal [Online] Vol:1 P.7-12 Available From: http://www.biomedsearch.com/nih/experiencewith-application-selective-polarized/24640656.html [Accessed: 25th may'2014]

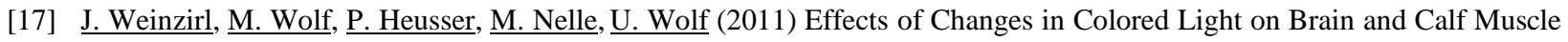
Blood Concentration and Oxygenation, The Scientific World Journal, [online] vol 1. p. 1216-1225. Available from: http://www.hindawi.com/journals/tswj/2011/370149/abs/ [Accessed: $3^{\text {rd }}$ Jun'2014]

[18] Ilse Truter (2006) COLOUR THERAPY "Using the energy of light in controlled 'doses'to affect healing" $S A$ Pharmaceutical journal [online] Department of Pharmacy, Nelson Mandela Metropolitan University, vol 73 (4) 56-58, Available from: http://reference.sabinet.co.za/webx/access/electronic journals/mp sapj/mp sapj v73 n4 a20.pdf [ Accessed: 29july'2014] 
[19] ASHUTOSH Karnatak (2010) Chromotherapy, An Alternate Method Of Treatment, Uses Colours To Cure Diseases Of The Mind And Body. Chromotherapy: Colourful Healing [online] vol: p. Available from: http://completewellbeing.com/article/colourful-healing/ [Accessed From: 20 June' 2014]

[20] Great saunas (2014) Chromo therapy-light can benefit our well being-824 [online] , Available from: http://www.greatsuanas.com/info.chromotherapy-light-therapy-in-infrared-sauna.cfm [Accessed: 2nd aug'2014]

[21] Colours, Colors And Their Frequencies [online] Available from: http://www.crystalinks.com/colors.html [Accessed on 4th Aug'2014]

[22] By Vijaya Kumar, (2003), Color Therapy Discover The Therapeutic Benefits Of Colors And How To Make Them Work For You, [online] New Delhi, Sterling Publishers Available from: http://books.google.com.pk/books?id=R23n4fKDB3wC\&printsec=frontcover\&dq=Color+Therapy+Discover+The+Therap eutic+Benefits+Of+Colors+And+How+To+Make+Them+Work+For+You+by+Vijaya\&hl=en\&sa=X\&ei=pmEPVO78JM XiaJWegZAH\&ved=0CCMQ6AEwAQ\#v=onepage\&q\&f=false [Accessed:15 ${ }^{\text {th }}$ Aug'2014]

[23] D. Asis, A. Yoshizumi, F. Luz, (2012), Auricular Chromotherapy: a novel technique in the treatment of psychological trauma, Akupunktur The Journal Of Acupuncture And Related Techniques, [online] vol 55(4) p:9-11 Available from: http://www.spma.pt/wp-content/uploads/2014/03/Artigo-publicado-na-Alemanha.pdf [Accessed:25 ${ }^{\text {th }}$ July'2014]

[24] Terry Oleson, Richard G Neimtzow (2014) Auriculotherapy Manual, Chineses And Western Systems In Ear Accupuncture $4^{\text {th }}$ Edition, [online] China Churchill Livingstone Elsevier Publications Available from: http://books.google.com.pk/books?id=QXVYAQAAQBAJ\&printsec=frontcover\&dq=Auriculotherapy + Manual, + Chinese + And+Western+Systems+In+Ear+Acupuncture \&hl=en\&sa=X\&ei=FmQPVL_RNcPUatyrgeAP\&ved=0CBoQ6AEwAA\#v= onepage \&q=Auriculotherapy $\% 20$ Manual $\% 2 \mathrm{C} \% 20 \mathrm{Chinese} \% 20 \mathrm{And} \% 20 \mathrm{Western} \% 20$ Systems $\% 20 \mathrm{In} \% 20$ Ear $\% 20$ Acupunct ure $\& f=$ false [Accessed:28 ${ }^{\text {th }}$ Aug'2014]

[25] Memon Shakeel (2011) Alternative System Of Medicine In India, International Research Journal Of Pharmacy [Online] vol 2(4) p.29-37 Avalaible From: http://www.irjponline.com/admin/php/uploads/vol2/issue4/5.pdf [Accessed On: 29 July'2014]

[26] R. Hari, Tanushree Poddar, (2011), The Magic Therapy of Colours: Holistic Healing Through Colours, [online] New Delhi, $\mathrm{V}$ and $\mathrm{S}$ publishers Available from: http://books.google.com.pk/books?id=bQJamkOnQ$\mathrm{sC} \&$ printsec $=$ frontcover $\& \mathrm{dq}=$ The + Magic + Therapy+of + Colours $:+$ Holistic + Healing + Through + Colours \&hl $=$ en\&sa $=X \& e i=$ 0GUPVLL1H4ntaKS0gYgD\&ved=0CBoQ6AEwAA\#v=onepage\&q=The\%20Magic\%20Therapy\%20of\%20Colours\%3A \%20Holistic\%20Healing\%20Through\%20Colours\&f=false [Accessed:6th Aug'2014]

[27] Xinjun Zhao (2014) Department of Industrial Design Northeastern University Shenyang, China . Research and Analysis on Non-medical Approaches to Alleviate Fatigue International Conference on Global Economy, Commerce and Service Science, [online] p.253-255 Available from: http://www.atlantis-press.com/php/pub.php?publication=gecss$14 \&$ frame $=\mathrm{http} \% 3 \mathrm{~A} / / \mathrm{www}$.atlantis-press.com/php/paper-

details.php\%3Ffrom\%3Dauthor\%2520index\%26id\%3D10982\%26querystr\%3Dauthorstr\%253DZ\%2526publication\%253 Dgecss-14 [Accessed On 15 ${ }^{\text {th }}$ Aug'2014]

[28] Samina Tazayyen Yousuf Azeemi (2009) A QUANTITATIVE STUDY ON CHROMOTHERAPY A QUANTITATIVE STUDY \{online] Available from: http://prr.hec.gov.pk/Thesis/373S.pdf [Accessed on:1st july'2014]

[29] Samina T. Yousuf Azeemi and Mohsin Raza, (2005),A Critical Analysis of Chromotherapy and its Scientific Evolution, Evidence Based Complementary And Alternative Medicine System, Volume 2, Issue 4, Pages: 481-488.

[30] Color therapy (2001) Available From: http://altered-state.com/index2.htm?/healing/colortheraphy.htm

[31] Sanja Radeljak (2008) Chromotherapy In The Regulation Of Neurohormonal Balance In Human Brain - Complementary Application In Modern Psychiatric Treatment, Chromotherapy In Psychiatric Treatment Collegium Antripologicum [Online], Vol 32 (2), P. 185-188 Available From: http://hrcak.srce.hr/index.php?show=clanak\&id_clanak_jezik=55497 [Accessed On:2 ${ }^{\text {nd }}$ Aug'2014]

[32] whirlpoolsystemoperations(chromotherapy), sanplast pure pleasure, Available from: http://www.sanplast.pl/en/knoeldgebase/whirlpool-system-options/ [ Accessed on2nd aug'2014]

[33] leadrshipcentral.com the opponent theory (2013), Available from: http://www.leadership-central.com/opponent-processtheory.html\#axzz3CdmXmpYn [Accessed on $5^{\text {th }}$ aug'2014]

[34] Vedic Cultural Fellowship (2003) http://www.vedicworld.org/chromo-therapy-to-the-ultimate-degree/

[35] Charles Klotsche, (1992), Color Medicine The Secrets Of Color/Vibrational Healing, USA, Light Technology Publishing.

[36] Chromotherpy ma sante au naturel (2004), Available from: http://www.ma-sante-au-naturelo.net/chromotherapy.html

[37] T A Kniazeva; (2006) Efficacy Of Chromotherapy In Patients With Hypertension, Vopr Kurortol Fizioter Lech Fiz Kult [online], $\quad$ vol: $\quad 1 \quad$ p. $\quad 3-11 \quad$ Avalibale http://www.researchgate.net/publication/7029758_Efficacy_of_chromotherapy_in_patients_with_hypertension [Accessed on: 10th July, 2014]

[38] Nancy Ann Tappe (2009), Understanding your life through color, USA, Aquila Libris, Publishing company 